\title{
Gearing up for Catalan Intellectual History: JOCIH's Twist
}

\author{
Pompeu Casanovas* (Data to Decisions Centre, La Trobe Law School, La Trobe University, Melbourne; \\ Institute of Law and Technology, Universitat Autònoma de Barcelona) \\ p.casanovasromeu@1atrobe.edu.au,pompeu.casanovas@uab.cat \\ http://orcid.org/0000-0002-0980-237

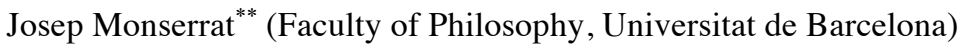 \\ jmonserrat@ub.edu http://orcid.org/0000-0002-8597-6138 \\ Wendy R. Simon ${ }^{* * *}$ (Universitat Abat Oliba CEU, Barcelona) \\ wendy@wendyrsimon.com http://orcid.org/0000-0001-6642-9617
}

\begin{abstract}
This article can be read as an Editorial for the first issue of the Journal of Catalan Intellectual History $(\mathrm{JOCIH})$ in its new stage at de Gruyter Open. It offers, first, a methodical review of the concept, roles, and trends of intellectual history in the 20th century. Next, it looks into the particular Catalan tradition, historiography, and cultural analysis to position the aim and the role of the Journal with regard to similar initiatives. It tries to give an answer to the crisis of intellectual history as a discipline, at the end of the past century. The third part of the article describes some of the available resources. The fourth section introduces the contents of the present issue, focussing on the construction of a collective identity and the literary engagement of Catalan writers between 1920 and 1980 , either in their country or in exile. The Notes of the present issue highlight the importance of technology, natural language processing, and Semantic Web developments in carrying out contemporary research in this field.
\end{abstract}

Keywords: intellectual history, social history, philosophy, linguistics, cultural studies, literary engagement, technology for Humanities.

\section{An Overview of Intellectual History}

Intellectual history is at the crossroad of several well-established fields in the Social Sciences and the Humanities - History, Philosophy, Anthropology, Philology, and Linguistics, among many others. All through

\footnotetext{
*Pompeu Casanovas has been recently appointed Research Professor at La Trobe University Law School (2017). He is Director of Advanced Research at the Autonomous University of Barcelona (UAB ), and founder and Head of the UAB Institute of Law and Technology (IDT-UAB). He works on the web of data, regulatory models, and their legal and ethical foundations.

** Josep Monserrat is at present Dean and Professor of Ancient and Political Philosopy at the Faculty of Philosophy of Universitat de Barcelona. He is Co-editor of Anuari de la Societat Catalana de Filosofia. He has worked mainly on Plato, Hobbes, and the recovery of Catalan intellectual heritage.

${ }^{* * *}$ Wendy R. Simon is $\mathrm{PhD}$ in Philosophy with a dissertation on "A lockean approach to examining the development and sustainability of contemporary democracies". She is Lecturer of Political Modern Philosopy at Universitat Abat Oliba (Barcelona).
} 
the 20th century, stemming from the First World War, it has been striving to settle itself as an academic field, able to furnish academic positions and holding a respectable position in Departments of History, Philosophy, Political Science, or Cultural Studies. However, compared to sister fields, this attempt has not been always as successful as expected. A brief overview of the existing literature sheds light on a permanent methodological crisis or self-questioning of the discipline. On the edge of intellectual creativity and scientific explanation, intellectual history includes a mixture of acute cultural reflections, sharp political criticism, philosophical analysis, and the expansion of conceptual boundaries that have been contested as a legitimate approach to culture and thought. To put it succinctly, "intellectual historians often make empirical claims, but can never know for certain if these claims are right" (Blau 2011, 358). However, this concern was precisely one of the main issues from which the field emerged and its helmsmen wanted to posit.

In the 1940s, after the inception of Arthur Lovejoy's Journal of the History of Ideas in 1940, Franklin Baumer (1949) put forth four main problems that ought to be faced: (i) discovering the climate of opinion or the Zeitgeist of particular periods of history; (ii) the problem of causation, i.e. the causes of intellectual change; (iii) the effects in the "world of action" - "to what extent and precisely how do ideas affect the majority of nonintellectual people"?; (iv) the uses of intellectual history - why study it? This kind of questions entailed explicitly that intellectual history was most needed to understand civilisation and preserve freedom after the Second World War, for it "has its uses for formulating a philosophy of history", suggesting possibilities of control as well as of prediction. "At the present time, we Westerners are at sea intellectually" (Baumer 1949, 202).

Democracy, individualism, class, race prejudice, anti-intellectualism... were understood as interdisciplinary concepts to be analysed internally (in relation) and externally (in context), as well as put in place for a "deeper understanding of the American mind" (Higham 1951, 471). In fact, American thinkers devoted the next 2 decades to find their own answers, including the differences between intellectual history, history of ideas, and history of philosophy. ${ }^{1}$

There was also a traditional European mass of work already done, stemming from the philosophical traditions of British Enlightenment and empiricism, French positivist sociology, and German Geistesgeschichte, phenomenology, and hermeneutics, which were widely used to define the trends, methods, and boundaries of this field as a discipline. ${ }^{2}$

Leonard Krieger $(1973,504-05)$ points at five identifiable schools of modern intellectual history, which dominated the first half of the century: (i) the German-Italian historicist school (featuring a mix of historical philosophers and philosophical historians running from Dilthey and Croce to Cassirer, Meinecke, and Carlo Antoni); (ii) the French group of historians known as École des Annales (Marc Bloch and Lucien Febvre); the American counterparts of these two European tendencies: (iii) first, the History of Ideas (Arthur O. Lovejoy and George Boas); (iv) and second, the group of the so-called New History (Robinson, Becker, and Bard); (v) finally, the historians of philosophical, literary, artistic, legal, and political theories - Bury, Barker, Randall, Sabine, Auerbach, Mornet, Laski, and so on. These trends represented a ground to build upon that could not be ignored. We can add to this account the seminal work carried out in the inter-war period or immediately after the Second World War by political philosophers with a European background - the Frankfurt School, Isaiah Berlin, and Hannah Arendt.

In the 1970s and 1980s, the so-called "linguistic turn" came up, as a response to an apparently simple question: what are the appropriate procedures to adopt in the attempt to arrive at an understanding of a text, a book, a literary or philosophical work, as a whole? (Skinner 1969) "Intellectualist" and "contextualist" methods coming from both European and American traditions constituted the two poles of inquiry in which developments occurred (Kelley 1987, 2005). The Cambridge School of political thought led by Quentin Skinner, John Pockok, and Peter Laslett proposed a careful re-examination of Renaissance and the Common Law tradition, stressing the importance of the implicit context - the pragmatic dimension of language - to properly understand the intention,

\footnotetext{
${ }^{1}$ See Boas (1948), Higham (1951, 1954, 1961), Greene (1957), Mandelbaum (1965), Grafton (2006).

${ }^{2}$ See Stern (1985), Richter (1987), Kelley $(1987,2005)$, Palti (2010).
} 
meaning, and scope of intellectual works in history. Other scholars, such as William Bouwsma, turned to exploring the behavioural and semantic side of meaning, following the "thick description" trend proposed by philosopher Gilbert Ryle and anthropologist Clifford Geertz.

Almost paradoxically, this linguistic turn, which added complexity to the field, was in the end incorporated into the regular toolkit of social historians and this fact led to an internal crisis. In 1981, Bouwsma wrote: "The decline of intellectual history appears obvious, and probably irreversible" $(1981,279)$. In the same vein, Grafton proposed $(2006,1)$ :

Social history, after all, had captured the minds of a generation or a large percentage of it in the 1960s, thanks both to the power of its own new method and vision and to the political conditions that inspired so many historians to dedicate themselves to recovering the experience of those who had not had power, voice or privilege in the past. From the 1960s on, the study of core texts and writers would undergo siege after siege, from the era when "irrelevance" formed the central charge against it to the later age of the culture wars, when tragedy repeated itself as farce. Even more important, intellectual history had genuinely lost its edge and coherence in the same period. The collapse of liberalism in the 1960s undermined the Americanist pursuit of a unified "national mind," leaving the field open for social historians who emphasized the varied experiences of those groups that the older picture had omitted. Europeanists too found it impossible, by the 1960s, to draw the unified pictures of intellectual traditions and cultural periods that had occupied A.O. Lovejoy and Carl Becker. Instead they traced what amounted to intellectual biographies of individuals or groups, studies that were often erudite and insightful, but not methodologically distinct from the work of cultural historians or historians of science.

The linguistic turn facilitated other venues as well. The works by French philosophers, driven by semiotics, linguistics, and psychoanalysis, inspired many historians to open up the range of interpretations of culture as a privileged object of study. Discourse analysis and historical semiotics, sometimes referred to as structuralism and post-structuralism - Kristeva, Todorov, Foucault, and Derrida - had a huge impact, fostering the converse vision of reading human experience and thought as multidimensional textual networks. Intellectual historians, therefore, became "cuckoos in the historical nest". ${ }^{3}$ Under the revival of rhetoric, carried out e.g. by Hayden White, "the new intellectual historians undercut emphatic arguments with the truism of textual complexity".

In the 1990s and up to the end of the century, controversies on "historical knowledge" vs. "poietic reflection" arose. Dominick LaCapra, one of the main representatives of psychoanalytic discourse analysis, retaliated directly against such criticisms of "bloodless scholasticism and cold formalism":

Positivism is not science but scientism that takes a restricted model of science and tries to generalize it as the only valid way to approach problems. The result is a conception of research in terms of extreme objectification of the other wherein the status of the researcher as subject is itself occluded or at least not posed as a problem. In more psychoanalytic terms, I would define positivism as the denial or disavowal of our transferential relation to the object of study (including the past). (LaCapra 1992, 429)

Nevertheless, this is not a black-and-white issue. It all depends on the initial concerns and questions (both) that might develop and change along the many stages that a research can take. There are precise and apparently simple questions that foster long-term research works, able to shed light on an entire period. We can think of many examples in different times.

\footnotetext{
3“'Intellectual historians have become cuckoos in the historical nest. To the consternation of their colleagues they like to think and to talk about method - and thereby hang our tale. For the problem of intellectual history is not that, like political and institutional history, has a method too long unexamined or that, like social history, it has method modeled on more methodical disciplines and requiring adaptation. The problem of intellectual history, epitomized in the current disputes about the social relations of ideas, is that it has too many methods, that this plurality reflects the diversity of its objects, and that this diversity has raised serious doubts about its integrity as a distinct and autonomous field of history" (Krieger 1987, 499). 4" As with White, what begins as a call for a radical departure in historical thought closes sounding very familiar: the importance, complexity, and ambiguities of the text are continuously reiterated - a proposition advanced for decades by new and not-so-new literary critics. To be sure, what is familiar is neither bad nor wrong. Yet, as with White, in two respects the circle has been closed. The new intellectual historians undercut emphatic arguments with the truism of textual complexity." (Jacoby 1992, 418)
} 
Who planned and organised the plot that killed Giulano de Medicis, Lorenzo's brother, at the so-called Pazzi Conspiracy on 26 April 1478? What was the role of Pope Sixtus IV? Or, who was the girl who received as a gift van Gogh's ear from the painter's hands on 23 December 1888? What really happened that night? Or, back to Catalan culture during the first Dictatorship of Primo de Rivera, who was the professor with whom Miquel Carreras had a quarrel, preventing him, as a result, to be officially enrolled at the University of Barcelona Law School in 1924 ? What did the conflict really mean? ${ }^{5}$ We can understand the behaviour of early Renaissance states much better, the birth of contemporary art, or the breaking of 20th century nationalism if we are able to answer these seemingly straightforward questions. Attention to details, setting and crossing database contents, accurate inferences, comparative work, and especially new primary sources are needed to solve historical puzzles. It can take years to find some evidence and to test the working hypothesis before reaching some conclusions. It usually is a painstaking and time-consuming process - a detective work, as it has been described many times in the literature. Establishing "facts" is a complex intellectual task unfolding events, planning, and courses of action.

Be that as it may, LaCapra's works on transference, victimisation, and trauma deserve attention. ${ }^{6}$ There is also an interesting shift from "historical" to "intellectual" in this way of understanding what writers and readers do. The notion of transference in history, focussing onto individuals as social beings in close relation to collective identities and experiences with power, is not new. The Frankfurt School (e.g. Erik Fromm), legal realism (e.g. Jerome Frank), cultural history (e.g. Norbert Elias), medieval history (e.g. Pierre Legendre), and critical legal studies (e.g. Peter Goodrich) made a broad use of psychoanalytic notions in the 20th century. One way of considering them is questioning to what extent such approaches set up strong preliminary theoretical assumptions that might affect the ecological validity of their historical accounts. However, perhaps this perception would beg the question, preventing us from a deeper understanding of what intellectual history primarily does: making us think.

This specific literary layer focussing on the aims, attitudes, and the flesh and bones of authors is not oblivious to the passage of time. Twenty years ago, Harlan (1989) could write:

(...) after a hundred-year absence, literature has returned to history, unfurling her circus silks of metaphor and allegory, misprision and aporia, trace and sign, demanding that historians accept her mocking presence right at the heart of what they had once insisted was their own autonomous and truly scientific discipline. (Harlan 1989, 581)

Today, the emergence of the Internet, the Semantic Web, and Big Data in the beginning of the millennium has dramatically changed the cognitive ways of perceiving and representing our place in the world. As we will contend later, technology and artificial intelligence at the service of Humanities is the next step in historical analyses. We are experiencing a puzzling turning point, something already acknowledged in the Renaissance, on the edge of the modern era.

What is the sense of writing and reading over the past? What is the use of knowledge for? What is the use of self-knowledge for, if such a thing does exist? Who are we? Most of all, what are we doing? This parallels the same questions that Michel Eyquem, Montaigne, raised in his address to readers in the First book of the Essais: Ainsi, lecteur, je suis moi-même la matière de mon livre: il n'est pas raisonnable que tu emploies ton loisir en un sujet si frivole. It is worth remembering that Montaigne's most unknown role (because he remained silent about it) is the one of negotiator and mediator between the Catholic and Hugonote parties in the bloody French civil wars of the second half of the 16th century. Que sais-je? We should keep in mind that he knew much more than he wrote.

\footnotetext{
${ }^{5}$ The reader is kindly asked to refer the original works by M. Simonetta (2008), B. Murphy (2016), and A. Casanovas (2016)) to get the answers to these questions.

6 “ (...) by transference I mean pimarily one's implication in the other or the object of sudy with the tendency to repeat in one's own discourse or practice tendencies active in, or projected into, the other or object. For example, one may employ terrorising torture against presumed terrorists, have a ritualistic, phobic response to ritual, or replicate a scapegoat mechanism in an analysis of scapegoating (say, with respect to hisorians or other analysts who diagree with one's approach)." (LaCapra 2014, XV)
} 


\section{The Journal of Catalan Intellectual History}

The Journal of Catalan Intellectual History enters its second stage. The Journal was first presented at Ateneu Barcelonés by Salvador Giner, Vicenç Villatoro, and Ramon Alcoberro on 4 October 2011.7 A little later, on 14 November, it was introduced to a larger audience at the II Catalan Conference of Philosophy held in Sueca (Valence) addressed to the memory of Joan Fuster (Casaban and Sierra 2012). ${ }^{8}$

The Journal had originally two different names and was published in two languages with the same content: Revista d'Història de la Filosofia Catalana, in Catalan; and Journal of Catalan Intellectual History, in English. ${ }^{9}$ Perhaps a more neutral and less controversial denomination could have done the work as well. However, the answer to why we chose this name lies precisely on the many differential sides and dimensions of its subject matter. There is also some irony in it. Irony is a marker of distance and self-detachment praised by Catalan writers in the 20 th century. ${ }^{10}$

What are we talking about? In the United States, during the decade of the 1940s, 159 articles and 26 books about Herman Melville alone came out (Higham 1961, 33). In Catalonia, during the foundational period of the modern Catalan novel (1925-1930), the total amount of books published of all sorts was 1534 (Llanas, 2005). We cannot even think of a comparison based on the market or in terms of world impact. Nevertheless, during the first half of the century, a growing number of authors were determined to make a living writing exclusively in their native language.

Where did this "suicidal vocation" come from? ${ }^{11}$ Where did it take them? What have the values and limitations of their outcomes been? We do not know what could have happened if the Spanish Civil War (1936-1939) had led to a different political regime, but the collapse of the First Republic and the rise of fascism in Spain stopped this possibility dead. Literary and political engagement came along. It is not an exaggeration to say that the mere intellectual use of a language other than Spanish acquired an added political value in 20th-century Spain (Corretger et al. 2016). However, it would not be accurate either to bind Catalan culture into the boundaries of a natural language. Diglossia and the question about the public use of Catalan still foster passionate debates, and it is true that comparative studies are much needed (Murgades 2009, Marfany 2009).

Between 2011 and 2015, the JOCIH published both in Catalan and English many life-writings, biobibliographies, reviews, and research studies on Catalan, Valencian, and Majorcan thinkers (18th-20th centuries). Some of them, such as José Ferrater Mora, Joan Roura-Parella, Frederic Riu, Joaquim Xirau, and Eduard Nicol, spent their lives in exile after the Spanish Civil War (1936-1939), across several European countries, Latin America, and the United States. Other than in Catalan, they wrote mainly in the language of their host countries. The interested reader might have reasonable access to their works. However, this does not hold for other thinkers under the dictatorship of Primo de Rivera, the Spanish Republic, and early Francoism, such as Joan Crexells, Francesc Pujols, Miquel Carreras, Francesc Mirabent, Jaume Serra Húnter, Paul Ludwig Landsberg, and Joaquim Xirau i Palau. The Journal of Catalan Intellectual History tried to contribute to fill this gap.

In the first volume of the Journal, we published the revised text of the last lecture held by Miquel Batllori, just before his death in 2003. The eminent historian accepted to talk about his memories of Ignasi Casanovas, Balmes' biographer and editor of his Complete Works in 1925, and Frederic Clascar, biblist, one of the early

\footnotetext{
${ }^{7}$ There is an archived record of the original presentations at http://arxiudigital.ateneubcn.org/items/show/1322 .

${ }^{8}$ See http://www.valencia.edu/fce/2congres/

${ }^{9}$ http://www.raco.cat/index.php/JOCIH/issue/archive

${ }^{10}$ Philosophers, sociologists, and journalists stemming from different backgrounds and very different from each other show this same trait - Eugeni d'Ors, J.M. Ferrater Mora, Josep Pla, Joan Fuster, and Salvador Giner. In one of the founding texts of Catalan Noucentisme (Novecentism), d'Ors $(1911,82)$ referred irony "not to a dissimulation, as rhetoricians use to say, but to all incomplete intellectual adhesion”. See Martí Monterde (2006).

${ }^{11}$ See J. Castellanos $(2005,10)$ quoting Prudenci Bertrana: "There is no human force to divert he who has been born to suicide."
} 
scholars focussing on the outcomes of University of Cervera in the 18th century. His lecture started with the following words:

I would like to begin with a small anecdote on the question as to whether there is such a thing as "Catalan" philosophy. Whilst teaching at Harvard, Juan Marichal, publisher and scholar of the life and political works of Manuel Azaña, was asked by an American colleague what he taught there. On receiving the answer "the History of Latin America Thought", the colleague replied, 'Is there such a thing?' In North America, some people knew absolutely nothing about the subject. This lack of knowledge probably embraces Catalan philosophy. (Batllori 2011,27)

We are afraid that this is still the situation for the main bulk of Modern and Contemporary Catalan intellectual history. Batllori devoted his life and 19 thick volumes to the political history of Catalonia, Aragon, Valence, and Majorca, with special reference to their poets, writers, and thinkers from the 12th-20th centuries. Having taught for 30 years at the Pontificia Università Gregoriana, as well as having directed the Archivum Historicum Societatis Iesu in Rome, he invariably started his many works with an accurate examination of primary sources and available manuscripts - held, among many others, in the Vatican Archive (including the Secret one), and the General Archive of the Crown of Aragon. ${ }^{12}$ Had his Complete Works been published in English, there is no doubt that we would be talking about one of the most widely read historians of culture of the 21 st century. But, as many other scholars of his generation, he was one of the "suicidal" writers that decided to raise his scientific building mainly in Catalan - the same language used by the Borja (Borgia) family in their private letters, which he started editing at Diplomatari Borja in 2002 (Duran 2009).$^{13}$ Grown in a native Spanish-speaking family (his mother was Cuban), it is worth noticing that he had to make up his mind about it (Alcoberro 2000, Batllori, 2003).

It can be argued that these assertions are not absolute and should be nuanced. Indeed, Batllori is recognised worldwide as a giant figure by his fellow historians, and English could be considered only a contemporary lingua franca. Both issues are related. However, while the first statement is entirely faithful, we are not convinced that the latter one is equally true. English in the 21 st century is not Latin in Post-renaissance Europe. It is becoming a second natural language for many non-native speakers in a global society (think of the Netherlands and Scandinavian countries, not to mention Asia). We will come back to this.

There is another central figure to which JOCIH devoted a volume (number 7) in 2014. José Ferrater Mora is well known as the author of the Diccionario de Filosofía (1976), written in Spanish. This is a Herculean achievement. As noticed many times by his friend and fellow philosopher Jesús Mosterín, it only compares to Macmillan's Encyclopaedia of Philosophy edited in 1967 by Paul Edwards. However, this Encyclopaedia with about 1.500 entries is due to the work of more than 500 contributors. Instead, Ferrater wrote entirely by himself the 3.154 entries that his Dictionary embraces (Mosterín 2001). It is our contention that it counts as intellectual history, for it encompasses ontological and epistemological decisions drawing a specific comparative methodology ${ }^{14}-\mathrm{a}$ “'weak' or 'informal' recursive procedure in historiography" (Ferrater 1982). It is worth mentioning that, shortly after his arrival at Bryn Mawr College in 1949, he witnessed in the 1950s the emergence of the discipline. He published twice in the Journal of the Ideas (Ferrater 1953, 1956), and had a firsthand acquaintance with the main players of its philosophical side (including Freuer, Friess, and Mandelbaum).

Nowadays, there is certainly a plurality of economic, anthropological, political, and social research lines on Catalan history. Medieval history is flourishing more than ever, and so are Modern and Contemporary studies. As had happened in Europe and USA during the past 30 years, historiography and social history have

\footnotetext{
${ }^{12}$ The General Archive was founded in 1318 in Barcelona by the king James II of Aragon the Just (including all its terrotories). It was the single central archive of the Crown from 1318 to 1348, in which the Courts of Zaragoza created the Archive of the Kingdom of Aragon. In 1419 also was created the Royal Archives of Valencia, where were deposited the funds of the courts of economic control of the administration of the kingdom and the Rational Master File (financial and tax documents) of the Kingdom of Valencia.

${ }^{13}$ This is the general project of editing in fifty volumes the documents of the whole Borgia family, cfr. http://www.elsborja.cat/linstitut-internacional-destudis-borgians/publicacions-de-liieb/diplomatari-borja/

${ }^{14}$ See Casanovas $(2013,2014)$ for a further analysis of Ferrater's intellectual history.
} 
incorporated biographies and qualitative data analysis on the subject matters that once had been the main object of intellectual history - especially nationalism, institutional analysis, and culture (Simon, 2006, 2008). Jordi Casassas $(1998,2005)$, one of the first to draw attention to the subject, detached the study of "professional intellectuals" from it:

As I understand it, cultural history should not be confused with intellectual history, which is more endogenous and discourse analysis-centred. Anyway, while not rejecting it, rather than analysis of the particular discourse, what matters is the common production, the setting of general trends, fames and exclusions, politics and common cultural practices. What links is social history, politics, or power, rather than intellectual history. (Casassas 1998,7)

At present, we think it is better to single out the synergies and concomitances rather than the differences. The cognitive dimension of human beings is a complex one. We could differentiate several dimensions to describe and explain their outcomes and the construction of human societies - epistemic (e.g. the emergence of collective properties in perception and reasoning), analytical (e.g. knowledge representation languages), ontological (e.g. what social entities are referred to), and methodological (e.g. which procedures and steps are followed within the knowledge acquisition process). At the theoretical level, historiography and social history invariably meet other disciplines, as advanced by intellectual history of the inter- and post-war periods.

Reaching a fair understanding of intellectual and creative contributions to society (or social ecosystems) Gaudi's architecture in the 20th century or Llull's conceptual maps in the edge of the 14th century - requires not only fleshing out a social explanation, but redesigning the original thought into other languages. For instance, we can get a better understanding of Llull's distinctions and instrumental outcomes if we plot them into mathematical graph theory, natural language processing, and learning machine programming (Bonner 2006, Fidora and Sierra 2011). This is a common endeavour, especially urged in the upcoming society based on information processing. A quick look to the construction of artificial societies and the socio-technical and sociocognitive artificial systems may help to identify the social components of their hybrid nature (Noriega et al. 2016). In the so-called Web 2.0 (the Social Web) and Web 3.0 (the Semantic Web), individuals live and communicate through "quantified selves", i.e. the massive production and aggregation of data about their behaviour, mind, and body.

\section{Resources and Journals on Catalan Studies}

It should be stressed that Catalan is a minority language, ranking 75th according to the number of primary and secondary speakers (8-10 million), but with a stronger impact on the Web. ${ }^{15}$ By February 2017, Viquipèdia (Catalan Wikipedia) reached 539,819 articles $^{16}, 13,509$ views per hour, and 53 editors per million speakers. ${ }^{17}$ This is not a particular feature: non-dominant languages (such as Basque, Estonian, and Icelandic) tend to outperform on the Web to increase and strengthen their presence. Natural languages, not only as knowledge, but as structured data, have positive side effects in their maintenance and strength related to inner and outer communities of speakers.

Secondary resources, digital libraries, and Linked Open Data are changing the way intellectual history has been performed so far. It certainly facilitates the access to a huge bulk density of documents. However, this is the least of its functions: its real power lies on the possibility of structuring, storing, clustering, ordering, and handling the content of cultural and intellectual data. It clears the way to finding unknown patterns of knowledge and behaviour that are able to change our present theories and our understanding of the past (Meroño-Peñuela 2013). It is precisely this understanding that we are seeking for.

\footnotetext{
${ }^{15}$ See http://www.wiccac.cat/2017/03/barometre-de-lus-del-catala-a-internet-marc-2017/

${ }^{16} \mathrm{https://ca.wikipedia.org/wiki/Especial:Estad \% C3 \% ADstiques}$

17 https://stats.wikimedia.org/CA/TablesCurrentStatusVerbose.htm
} 
Some digital tools are helping in the access, visibility, and manageability of academic content on specialised subjects. The open access repository RACO - Catalan Journals in Open Access/Revistes Catalanes en Accés Obert $^{18}$ - contains 465 journals, including l'Anuari de la Societat Catalana de Filosofia ${ }^{19}$, Arxiu de Textos Catalans Antics $^{20}$, AUSA $^{21}$, Itaca: Quaderns Catalans de Cultura Clàssica ${ }^{22}$, Barcelona quaderns d'història ${ }^{23}$, Butlletí de la Societat Catalana d'Estudis Històrics ${ }^{24}$, Caplletra: Revista Internacional de Filologia ${ }^{25}$, Catalan Historical Review ${ }^{26}$, Catalan Social Sciences Review ${ }^{27}$, Enrahonar: an international journal of theoretical and practical reason ${ }^{28}$, Estudis Romànics ${ }^{29}$ Comprendre: Revista Catalana de Filosofia $^{30}$, Digithum: revista digital d'humanitats $^{31}$, Imago Temporis: medium Aevum ${ }^{32}$, InDret ${ }^{33}$, Lengua i literatura ${ }^{34}$, Lletres de Filosofia $i$ Humanitats $^{35}$, Magnificat: cultura i literatura medievals ${ }^{36}$, Manuscrits: Revista d'Història Moderna ${ }^{37}$, Els Marges: revista de Llengua i Literatura ${ }^{38}$, Medievalia: Revista d'Estudis Medievals ${ }^{39}$, Mirabilia: electronic journal of antiquity and middle ages ${ }^{40}$, Pedralbes: Revista d'Història Moderna ${ }^{41}$, Revista de Dret Històric Català $^{42}$, Segle XX: Revista Catalana d'Història ${ }^{43}$, Revista del Centre de Lectura de Reus ${ }^{44}$, SVUMMA: Revista de Cultures Medievals ${ }^{45}$, Taula: Quaderns de Pensament ${ }^{46}, 452^{\circ} \mathrm{F}$ : Revista de Teoría de la Literatura y Literatura Comparada ${ }^{47}$, 1611: Revista de Historia de la Traducción ${ }^{48}$.

Some more repositories and databases are already available in open access for research purposes. ARCA Archive of Old Catalan Journals/Arxiu de Revistes Catalanes Antigues - is an open portal giving access to the complete collection of ancient texts and images held at the Biblioteca de Catalunya. ${ }^{49}$ It includes 365 journals and about two million documents. The Digital Memory of Catalonia (MDC) is a cooperative open access repository containing digitalised collections related to its cultural heritage. ${ }^{50}$ Trencadís is an open access repository of local media. ${ }^{51}$

We are not alone in our commitment with Catalan intellectual history. The Ferrater Mora Chair of Contemporary Thought/Càtedra Ferrater Mora de Pensament Contemporani is carrying out significant research and

\footnotetext{
${ }^{18} \mathrm{http}: / / \mathrm{www} . c s u c . c a t / e n /$ libraries-cbuc/catalan-journals-in-open-access-raco

${ }^{19} \mathrm{http} / / \mathrm{www}$.raco.cat/index.php/AnuariFilosofia

${ }^{20} \mathrm{http}: / /$ www.raco.cat/index.php/ArxiuTextos/issue/archive

${ }^{21} \mathrm{http} / / / \mathrm{www}$.raco.cat/index.php/Ausa

${ }^{22} \mathrm{http} / / / \mathrm{www} \cdot \mathrm{raco} . c a t / \mathrm{index} \cdot \mathrm{php} / \mathrm{Itaca}$

${ }^{23}$ http://www .raco.cat/index.php/BCNQuadernsHistoria

${ }^{24} \mathrm{http}: / / \mathrm{www}$.raco.cat/index.php/ButlletiSCEH

${ }^{25} \mathrm{http} / / / \mathrm{www}$.raco.cat/index.php/Caplletra

${ }^{26} \mathrm{http}: / / \mathrm{www}$.raco.cat/index.php/CatalanHistoricalReview

${ }^{27} \mathrm{http} / / / \mathrm{www}$.raco.cat/index.php/CSSR

${ }^{28} \mathrm{http} / / / \mathrm{www} \cdot$ raco.cat/index.php/Enrahonar

${ }^{29} \mathrm{http}: / / \mathrm{www} \cdot$ raco.cat/index.php/Estudis

${ }^{30} \mathrm{http}: / /$ www.raco.cat/index.php/Comprendre

${ }^{31} \mathrm{http}: / / \mathrm{www} \cdot$.raco.cat/index.php/Digit

${ }^{32} \mathrm{http} / / / \mathrm{www}$.raco.cat/index.php/ImagoTemporis

${ }^{33} \mathrm{http} / / / \mathrm{www}$.raco.cat/index.php/InDret

${ }^{34} \mathrm{http}$ ://www .raco.cat/index.php/LlenguaLiteratura

${ }_{35}^{35} \mathrm{http}: / /$ www.raco.cat/index.php/LletresFilo

${ }^{36} \mathrm{http} / / / \mathrm{www}$.raco.cat/index.php/MagnificatCLM

${ }_{37} \mathrm{http} / / / \mathrm{www}$.raco.cat/index.php/Manuscrits

${ }^{38} \mathrm{http}: / /$ www $\cdot$ raco.cat/index.php/Marges

${ }^{39} \mathrm{http}: / / \mathrm{www}$.raco.cat/index.php/Medievalia

${ }^{40} \mathrm{http} / / / \mathrm{www}$.raco.cat/index.php/Mirabilia

${ }^{41} \mathrm{http}: / / \mathrm{www} \cdot$.raco.cat/index.php/Pedralbes

${ }^{42} \mathrm{http} / / / \mathrm{www} \cdot$ raco.cat/index.php/RevistaDretHistoric

${ }^{43}$ http://www.raco.cat/index.php/SegleXX

${ }^{44} \mathrm{http}: / /$ www.raco.cat/index.php/RevistaCLR

${ }^{45}$ http://www.raco.cat/index.php/SVMMA

${ }^{46} \mathrm{http} / / / \mathrm{www}$.raco.cat/index.php/Taula

${ }^{47} \mathrm{http}: / /$ www.raco.cat/index.php/452F

${ }^{48}$ http://www .raco.cat/index.php/1611

${ }^{49} \mathrm{http} / / / \mathrm{www} \cdot$ bnc.cat/digital/arca/angles/index.html

${ }^{50} \mathrm{http} / / \mathrm{mdc} 1$.cbuc.cat/

${ }^{51} \mathrm{http}: / /$ trencadis.diba.cat/
} 
dissemination tasks at the University of Girona. ${ }^{52} \mathrm{We}$ owe to the Chair, among other initiatives, the digitalisation of the philosopher's personal documentation ${ }^{53}$. The Institut d'Estudis Catalans (IEC) and its many scientific societies are doing a formidable job since its foundation in $1907 .{ }^{54}$ The JOCIH is one of the outcomes of one of these societies, namely, the Catalan Society of Philosophy/Societat Catalana de Filosofia. The Autonomous University of Barcelona, by means of the UAB Institute of Law and Technology ${ }^{55}$ is publishing it along with some of its members. La Trobe University has recently joined this initiative as well.

In the English-speaking world, the Anglo-Catalan Society (since 1954) ${ }^{56}$, the North American Catalan Society (since 1978) ${ }^{57}$, and the PEN Club International rank first in a true interest on Catalan culture. ${ }^{58}$ The Catalan PEN/PEN Català is active since $1922 .{ }^{59}$ The Journal of Catalan Studies ${ }^{60}$ and the Catalan Review: International Journal of Catalan Culture ${ }^{61}$ address the need to foster exchanges and disseminate scientific findings (mainly on language) and cultural and literary essays over a large number of subjects. The first one was launched in 2005, following the Anglo-Catalan Society Occasional Publications (ACSOP). ${ }^{62}$ The second one was issued in 1986, edited by Josep Roca-Pons (Indiana) and Manuel Duran (Yale) ${ }^{63}$

It is worth noticing that different orientations coexist under the same label at the international level. Catalan Studies are usually located in Departments of Modern Languages (UK), Romance Languages (USA), Spanish and Portuguese (UK/USA), or Spanish and Latin American Studies (Australia). There is a tendency to understand Catalan culture as integrated into the Hispanic world (within Spanish, Portuguese, and LatinoAmerican culture and literature), while other research and teaching organisations conceive it in a more autonomous way, closer to Mediterranean and South European cultures. ${ }^{64}$ Perhaps this is not a sharp divide, accepting many blurred mixtures, but it reflects the institutional shape of the academic work.

We should mention the European journals as well. The German Zeitschrift für Katalanistik/Revista d'Estudis Catalans $^{65}$, is a journal on linguistics and literature, edited in Freiburg im Breisgauby (Baden-Württemberg) by Tilbert Dídac Stegmann and Brigitte Schlieben-Lange since 1988, as the Journal of Deutsch-Katalanische Gesellschaft (Deutsche Katalanistenverban/Associació Germano-Catalana ${ }^{66}$ since 1997). In France, the Revue $d^{\prime} E t u d e s$ Catalanes (REC ${ }^{67}$ was founded in 1998 by Christian Camps at Université Montpellier III, as the Journal of Association Française des Catalanistes (AFC) ${ }^{68}$ The Rivista Italiana di Studi Catalani ${ }^{69}$ is the Journal of Associazione Italiana di Studi Catalani (AISC) ${ }^{70}$. AISC is active since 1978, and the journal was founded by Patrizio Rigobon, Annamaria Annicchiarico, among other scholars, in 2011.

\footnotetext{
${ }^{52}$ http://www.catedraferratermora.cat/

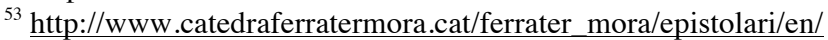

${ }_{54}^{54} \mathrm{http} / / / \mathrm{www}$.iec.cat/activitats/entrada.asp

55 http://idt.uab.cat/

${ }^{56}$ The evolution of the Society "has mirrored developments in the Països Catalans themselves, as the recovery of political autonomy has been attended by a process of normalized social use of the Catalan language and by a renewed surge in the traditional dynamism of Catalan culture". http://www.anglo-catalan.org/about-us.html

57 "The North American Catalan Society (NACS) is a professional association of scholars, students, and people with a general interest in any aspect of Catalan culture (literature, linguistics, visual and performing arts, history, and philosophy, among other disciplines)." http://nacs.espais.iec.cat/

${ }^{58}$ http://nacs.espais.iec.cat/

${ }^{59} \mathrm{http://www.pencatala.cat/}$

${ }^{60} \mathrm{http}: / /$ jocs.anglo-catalan.org/ojsnew/index.php/jocs/index

${ }^{61} \mathrm{http} / / /$ online.liverpooluniversitypress.co.uk/loi/catr

${ }^{62} \mathrm{http} / / / \mathrm{www}$.anglo-catalan.org/publications.html

${ }^{63}$ Duran, with W. Kublack, is the author of Reason in Exile: Essays on Catalan Philosophy (1994), one of the first books on this subject.

${ }^{64} \mathrm{http}: / / \mathrm{www} . i e c . c a t /$ institucio/documents/18825_OrientacionsEstrategiques2009-2018.pdf

${ }^{65} \mathrm{http} / / / \mathrm{www}$.romanistik.uni-freiburg.de/pusch/zfk/

${ }^{66} \mathrm{http} / / /$ www.katalanistik.de/

${ }^{67} \mathrm{http://france-catalaniste.com/documentation/rec \# NOUVELLE}$

${ }^{68} \mathrm{http}$ ://france-catalaniste.com/index.php

${ }^{69} \mathrm{http} / / /$ riscat.ediorso.it/2016/08/15/la-rivista-italiana-di-studi-catalani/

${ }^{70} \mathrm{http}: / / \mathrm{www}$.aisc.cat/
} 
Last but not the least, the Asociación de Catalanistas de América Latina (ACAL) has been very active from 2012 onwards in promoting Catalan Studies and their relationship with the many countries of Latin America. It has recently sponsored two International Colloquia, in Puebla (Mexico) in 2015 and 2017, and several publications. ${ }^{71}$

\section{About the Contents of This Volume}

The new issues of the Journal, including the present one, will be published on the de Gruyter Open platform. Our aim remains the same: plus ça change, plus devient la même chose. We will welcome interdisciplinary works and reflections on past and present intellectual Catalan history, memory, and culture. It is not our aim to impose or clear-cut in any way how to approach this subject. Writers should be able to write freely.

However, we do believe that there is still room for improvement in many ways. The first urgent task is to recuperate the works that have been lost, forgotten, or simply ignored. Archives and libraries should be explored and mined. If we set up fragile scaffolds with many uncovered places and holes on the historical canvas, each young generation will be bound to reconstruct by its own an incomplete intellectual patchwork. It comes as a surprise sometimes that when the past is finally revealed, findings are treated as a dead sea and put aside as outdated or flawed. This attitude finds no shoulders to rest upon. A cultural tradition is alive when it is considered useful and actually used to fertilise ongoing research. Thus, the second task is linking this tradition with contemporary developments. This proposal entails going a bit beyond history, as ancient ideas can be actually checked, re-enacted, and sometimes embodied into the new ones. This is not saying that Llullism or Pactism (Eiximenis) should be revamped as general underlying frameworks of thought or ignoring the fact that some outstanding figures - e.g. Miró, Gaudí, Dalí, and so on - are still alive. It is simpler than that: what we mean is that contrasting and normally quoting (when needed) artists, thinkers, and philosophers of the past into ongoing contemporary essays, art crafts, and research is an enriched and enriching way of going forward. What we should avoid is the totalitarian way of wiping out memory from intellectual and academic work and practices.

Let us introduce the contents of the present issue, now. It stems from the publication of El compromís literari en la modernitat: Del període d'entreguerres al postfranquisme (1920-1980) (Corretger, Casanovas, and Salvador 2016). Some papers have been rewritten and others have been added to show the sense and emergence of Catalan literature, struggling between the wars, the many exiles, and the loud silence of Francoism in the middle of the 20th century. Talking of trauma, identity, and several ways to construct and handle engagement through literature are at the centre of the volume. We have reserved the Section of Notes to reflect on science and research methodologies, as well as to disseminate the cultural labour of Ramon Llull Institute. ${ }^{72}$

In the Section of Articles, Francesc Vilanova puts forth a reflection on the notion of "cultural genocide". Could it be applied to the Catalan case? Jordi Male describes the making of Carles Riba's civic and literary sense of duty with regard to his readers, when hundreds of Catalanist professors were expelled from their positions in the dictatorship of Primo de Rivera (1923-1930). Magí Sunyer explores the late impact of Modernist ideals and aims on the writers of the Spanish First Republic (1931-1936), which returned, as Antoni Fuster did, to the anarchist subjects of madness and the individual. In a retrospective and reverse reading, Joan Cuscó puts forward the link between the modernist architecture of Gaudí, Pujols' hyparxiology in the 1920s, and the way Salvador Dalí made a later use of this heritage to construct his aesthetic views on identity (with Ramon Llull in the background).

Montserrat Corretger, in a seminal paper that is pivotal to this volume, explores how exiled writers, such as Domènec Guansé and Vicenç Riera Llorca, played a fundamental role in recovering Catalan historical collective

${ }^{71}$ http://acal.espais.iec.cat/ 
memory and identity. She relates their work to the theories of Lowenthal, Ricoeur, and Traverso regarding the past and memory. The so-called Chile group included Xavier Benguerel, Domènec Guansé, C.A. Jordana, Joan Oliver, and Francesc Trabal. Montserrat Bacardí's analysis focusses on their choice of translation as a way of cultural fighting from their Chilean exile after the Civil War.

Three articles on essays and literature under Franco come next. Francesc Foguet discloses the censorship reports on the essays written by Maria Aurèlia Campany between 1968 and 1978. General Franco's censorship apparatus worked until his death, in 1975. Xavier Ferré breaks down the work of Manuel de Pedrolo, one of the novelists with more impact on the Catalan society at the time. He points out that literary imagination became a form of criticising the ideological model of late Francoism. Vicent Salvador fathoms the notion of literature as social praxis due to Joan Fuster. He underscores the complexity of his particular literary patchwork, in which he critically examined the contradictory factors that shaped Spanish society under a totalitarian regime.

The review by Antoni Maestre-Brotons highlights the historiographical perspective of the essays included in Emili Samper's edition The Myths of the Republic: Literature and Identity (Reichenberger and Kassel, 2016). These essays are highly complementary with the content of the present issue.

The volume ends with four extended Notes. As said, we are opening a space on science and technology for Humanities. Scientific and aesthetic approaches can be bridged in many ways. Joan-Josep Vallbé foregrounds the connection between Gabriel Ferrater's poetry and Popper's falsationist model of philosophy of science. Two more Notes introduce the Semantic Web link with Humanities. Albert Meroño-Peñuelas briefly describes a solution for representing prototypical Digital Humanities datasets (History, Music, Philosophy, and so on) using the tools, formalisms, and languages provided by Linked Data and the Semantic Web. Anna D. Havinga and Adam Wyner provide an overview of two textual projects on Scottish history (1398-1531) - Law in the Aberdeen Council Registers (LACR), and A Text Analytic Approach to Rural and Urban Legal Histories (TAHL). We contend that these are essential linguistic tools for intellectual history.

The last Note, by Josep-Anton Fernàndez, gives an outline of the network of universities abroad teaching Catalan Studies, coordinated by the Institut Ramon Llull (IRL) (145 universities in 28 countries). In 1982, the Generalitat de Catalunya set up the Commission for the Promotion of the Teaching of Catalan Abroad (Comissió de Promoció de l'Ensenyament del Català a les Universitats de fora de l'Àmbit Territorial de Catalunya). From 2002 onwards, IRL coordinates and organises an extended international programme across universities (at present, 145 universities in 28 countries). This network will have regular access to the new issues of JOCIH published on the de Gruyter Open Access platform. We are grateful for the permanent support that we have received from the Institute, and we will post annual updates about its achievements.

Acknowledgements. Projects: Dialogue as a source of law, PR2015-S05 (IEC), Institut d'Estudis Catalans. UAB: Ajuts a la publicació de revistes periòdiques de recerca-2015.

\section{References}

Alcoberro, A: Miquel Batllori. Barcelona: Col.lecció de Biografies de la Fundació Catalana per la Recerca i la Innovació, 2003.

Batllori, M: Diplomatari Borja, 1: Documents de l'Arxiu del Regne de València (1299-1429), Miquel Batllori (Dir.), Luis Pablo Martínez i Miquel Navarro (Eds.), València: Edicions Tres i Quatre, 2002.

Batllori, M: Records de quasi un segle. G. Soler, C. Gatell (Eds.). Barcelona: Quaderns Crema.

${ }^{72}$ http://www.llull.cat/english/home/index.cfm 
Batllori, M: "Ignasi Casanovas and Frederic Clascar (2003)". Journal of Catalan Intellectual History 1(1) (2011): 27-45. Available at https://ddd.uab.cat/pub/jocih/jocih_a2011v1n1/jocih_a2011v1n1p27iENG.pdf

Baumer, F.L: "Intellectual history and its problems." The Journal of Modern History 21(3) (1949): 191-203.

Boas, G: "The role of protophilosophies in intellectual history." The Journal of Philosophy 45(25) (1948): 673684.

Bonner, A.: The art and logic of Ramon Llull: a user's guide. Vol. 95. Brill, 2007.

Bouwsma, W.J.: "From history of ideas to history of meaning". The New History: The1980s and beyond (II), The Journal of Interdisciplinary History 12(2) (1981): 279-291.

Brett, A.: "What is intellectual history now?" In: D. Cannadine (Ed.), What it is History Now? London: Palgrave Macmillan, 2002, pp. 113-131.

Casaban, E., Serra X. (Eds.): II Congrés Català de Filosofia. Joan Fuster, In Memoriam. Sueca, 9-11 novembre 2011, Departament de Lògica de la UV. València: Publicacions de la Universitat de València/Ed. Afers, Catarroja, 2012, pp. 445-453.

Casanovas, A: Miquel Carreras Costajussà (1905-1938). Olesa de Montserrat: Publicacions de l'Abadia de Montserrat, 2011.

Casanovas, P. "Josep Ferrater Mora i la història intel·lectual: mètode, ontologia i ontologies", Anuari de la Societat Catalana de Filosofia XXIV(2013): 63-111.

Casanovas, P. "Three theses on the historiography and ontology of Ferrater Mora." Journal of Catalan Intellectual History 7-8 (2014): 11-30.

Casanovas, P., Monserrat, J. and Serra, X.: "Journal of Catalan Intellectual History. Revista d'Història de la Filosofia Catalana", Zeitschrift für Katalanistik 24 (2011a): 303-316.

Casanovas, P., Monserrat, J. and Serra, X.: "Introduction. From one era to another", JOCIH 1-2 (2011b): 13-25. Available at: <http://revistes.iec.cat/index.php/JOCIH/article/view/49553/49716> (accessed February 15th 2017)

Casassas Ymbert, J.: Premsa cultural i intervenció política dels intel lectuals a la Catalunya contemporània (1814-1975). Barcelona: Edicions Universitat Barcelona, 2005.

Casassas Ymbert, J.: "La història cultural i l'intel· lectual professional. Una visió personal." Cercles: revista d'història cultural 1 (1998): 6-11.

Castellanos, J.: Escriure amb el ritme de la sang: la represa de la novel la catalana, 1925-1929: discurs de recepció. Barcelona: Institut d'Estudis Catalans, 2005.

Corretger, M.; Casanovas, P.; Salvador, V. (Eds.): El compromís literari en la modernitat: Del període d'entreguerres al postfranquisme (1920-1980). Vol. 38. Tarragona: RMIT/Publicacions Rovira i Virgili, 2016.

Darnton, R.: "First steps toward a history of reading". Australian Journal of French Studies 51 (2-3) (2014): 152-177.

D’Ors, E.: “Una contribución a la filosofía”. Cataluña, 175, 11 de febrero 2011: 81-82.

Duran, M.; Kublack, W.: Reason in Exile: Essays on Catalan Philosophy. Bern: Peter Lange, 1994.

Duran i Grau, E.: "The Borja Family: Historiography, Legend and Literature." Catalan Historical Review 1 (2009): 63-79.

Ferrater Mora, J: "Suárez and modern philosophy." Journal of the History of Ideas 14(4) (1953): 528-547. 
Ferrater Mora, J: "On the 'great analogy' [according to Milton C. Nahm]", Journal of the history of ideas 18(2) (1956): 280-284.

Ferrater Mora, J.: Diccionario de Filosofía, $6^{\text {th }}$ ed. Madrid: Alianza Editorial, 1976.

Ferrater Mora, J.: “The Languages of History”. Phenomenological Research, 43(2) (1982): 137-150.

Fidora, A., Sierra, C. (Eds.): Ramon Llull: From the Ars Magna to Artificial Intelligence. Barcelona: Artificial Intelligence Research Institute, 2011.

Furió, A.: "La historiografia catalana sota el franquisme”. In: A. Balcells (Ed.), Història de la historiografia catalana, Barcelona: IEC, 2004, pp. 205-228.

Grafton, A.: "The history of ideas: precept and practice, 1950-2000 and beyond." Journal of the History of Ideas 67(1) (2006): 1-32.

Greene, J.C.: "Objectives and Methods in Intellectual History." The Mississippi Valley Historical Review 44(1) (1957): 58-74.

Harlan, D.: "Intellectual history and the return of literature." The American Historical Review 94(3) 3 (1989):. 581-609.

Higham, J.: "The rise of American intellectual history." The American Historical Review 56(3) (1951): 453-471.

Higham,J.: "Intellectual history and its neighbors." Journal of the History of Ideas 15 (1/4) (1954): 339-347.

Higham, J.: "American intellectual history: A critical appraisal." American Quarterly 13(2) (1961): 219-233.

Jacoby, R.: "A new intellectual history?" The American Historical Review 97(2) (1992): 405-424.

Kelley, D.R.: "Horizons of intellectual history: retrospect, circumspect, prospect." Journal of the History of Ideas 48(1) (1987): 143-169.

Kelley, D.R.: "Intellectual history in a global age." Journal of the History of Ideas 66(2) (2005): 155-167.

Krieger, L.: "The autonomy of intellectual history." Journal of the History of Ideas 34(4) (1973): 499-516.

LaCapra, D.: "Intellectual history and its ways." The American Historical Review 97(2) (1992): 425-439.

LaCapra, D.: Writing history, writing trauma. Baltimore: John Hopkins University Press.

Levine, J.M.: "Intellectual history as history." Journal of the History of Ideas 66(2) (2005): 189-200.

Llanas, M.: Història de l'edició a Catalunya. L'edició a Catalunya: el segle XX (fins al 1939). Barcelona: Gremi d'Editors de Catalunya, 2005.

Mandelbaum, M.: "The history of ideas, intellectual history, and the history of philosophy." History and Theory 5 (1965): 33-66.

Marfany, J.L.: "Sobre la història de la diglòssia a Catalunya, encara. Resposta a Josep Murgades". Els Marges: revista de llengua i literatura, 88 (2009):105-114.

Martí Monterde, A.: "Ironies de l'assaig: Ors, Pla, Fuster: història intel. lectual de l'adhesió incompleta." Caplletra 41(Tardor 2006): 151-174.

Megill, A.: "Globalization and the History of Ideas." Journal of the History of Ideas 66(2) (2005): 179-187.

Meroño-Peñuela, A.: "Semantic Web for the Humanities." In: Extended Semantic Web Conference, Springer Berlin Heidelberg, 2013, pp. 465.649. 
Monserrat, J., Casanovas, P. (Eds.): Pensament i Filosofia a Catalunya, 3 vol. Barcelona: INEHCA, Societat Catalana de Filosofia. I: 1900-1923; II: 1924-1939; III. 1940-1975., 2002, 2003. Available at: Dipòsit Digital de Documents de la UAB, http://ddd.uab.cat/record/142577 (accessed February $15^{\text {th }}$ 2017)

Mosterín, J.: “Josep Ferrater Mora”. In: P. Casanovas (Ed.). Filosofia del segle XX a Catalunya: mirada retrospectiva. IV Cicle Aranguren. Aula de Ciència i Cultura 11. Sabadell: Fundació Caixa de Sabadell, 2001.

Miller, E.: "Intellectual history after the earthquakes: a study in discourse". The History Teacher 30(3) (1997): $357-371$

Müller, J.W.: "European Intellectual History as Contemporary History". Journal of Contemporary History 46(3) (2011): 574-590.

Murgades, J.: “D’una nació diglòssica (i també d'una altra de glotofàgica)”. Els Marges: revista de llengua $i$ literatura, 87 (2009): 107-115.

Murphy, B. Van Gogh's Ear. The True Story. London: Chatto \& Windows, 2016.

Nagypál, G.; Deswarte, R.; Oosthoek, J.: "Applying the semantic web: The VICODI experience in creating visual contextualization for history". Literary and Linguistic Computing 20(3) (2005): 327-349.

Noriega, P., Verhagen, H., d'Inverno, M. and Padget, J.: "A manifesto for conscientious design of hybrid online social systems.", $\quad$ COIN $++\quad 0 \quad @ \quad r \quad$ ECAI $\quad 2016 . \quad$ Available https://www.iiia.csic.es/sites/default/files/coinecai2016_paper_2.pdf (accessed 13 April 2017).

Palti, E.J.: "From ideas to concepts to metaphors: the German tradition of intellectual history and the complex fabric of language". History and Theory 49(2) (2010): 194-211.

Richter, M.: "Begriffsgeschichte and the History of Ideas". Journal of the History of Ideas 48(2) (1987): $247-$ 263.

Simon, A.: "Algunes consideracions sobre la trajectòria de la historiografia catalana recent". IDEES. Revista de temes contemporanis 28-29 (2006): 97-107.

Simon, A. (Dir.): Tendències de la historiografia catalana. València: Universitat de València, 2009.

Simonetta, M.: The Montefeltro Conspiracy. New York: Doubleday, 2008.

Skinner, Q.: "Meaning and Understanding in the History of Ideas". History and theory 8(1) (1969): 3-53.

Skinner, Q.: "Hermeneutics and the Role of History". New Literary History 7(1) (1975): 209-232.

Stern, L.: "Hermeneutics and intellectual history". Journal of the History of Ideas 46(2) (1985): 287-296. 